This item was submitted to Loughborough's Institutional Repository (https://dspace.lboro.ac.uk/) by the author and is made available under the following Creative Commons Licence conditions.

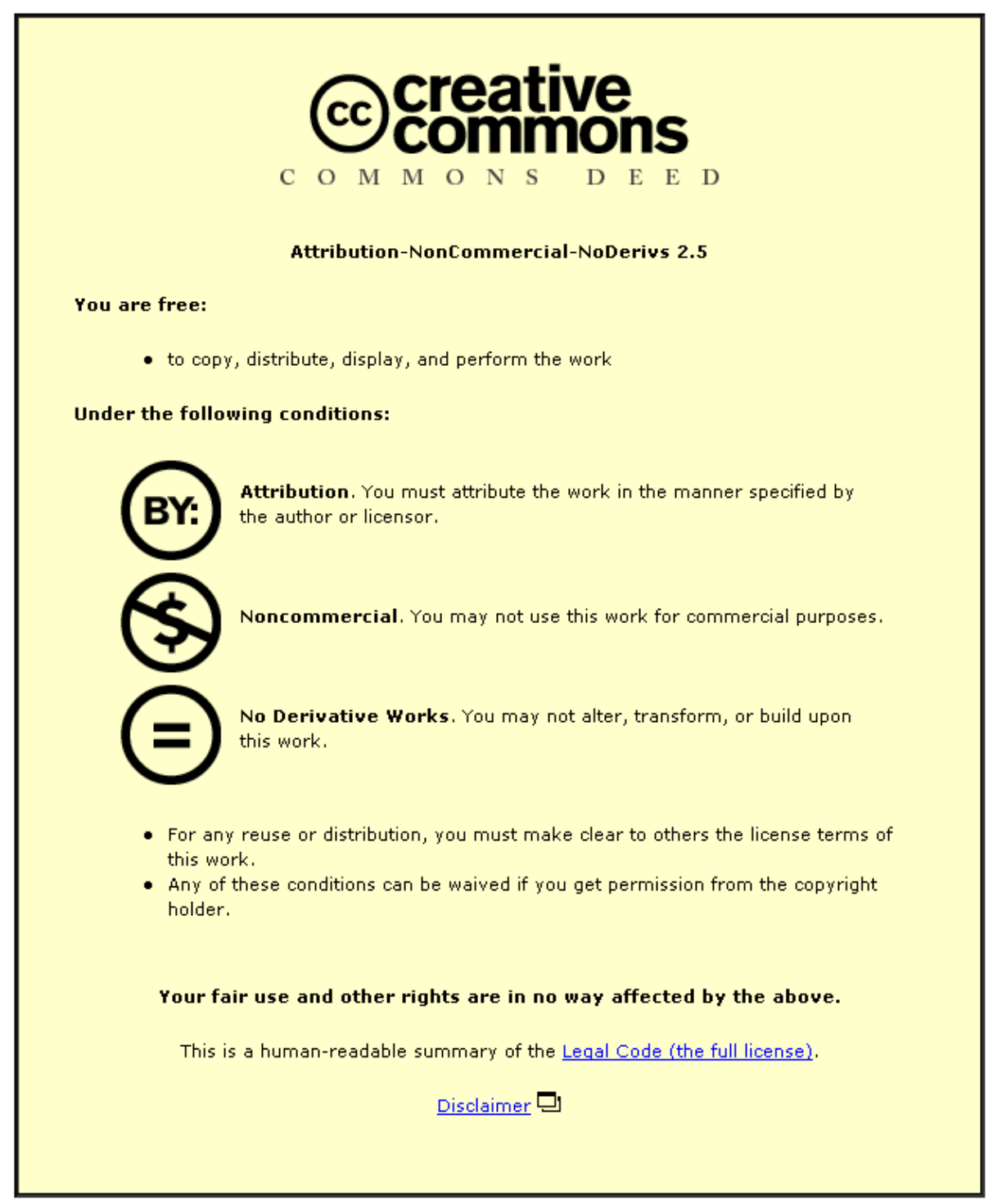

For the full text of this licence, please go to: http://creativecommons.org/licenses/by-nc-nd/2.5/ 
Waste and Resource Management Volume 166 Issue WR3

Design waste mapping: a project life cycle approach Osmani

ice | proceedings
Proceedings of the Institution of Civil Engineers

Waste and Resource Management 166

August 2013 Issue WR3

Pages 114-127 http://dx.doi.org/10.1680/warm.13.00013

Paper 1300013

Received 11/03/2013 Accepted 09/05/2013

Keywords: building, structures \& design/research \&

development/waste management \& disposal

\section{Design waste mapping: a project life cycle approach}

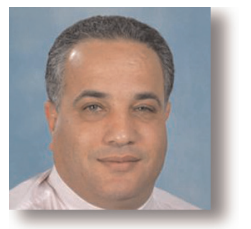

Mohamed Osmani

Senior Lecturer and Architectural Engineering and Design Management

Programme Director, School of Civil and Building Engineering,

Loughborough University, Loughborough, UK

An ever-increasing amount of global research on construction waste has been conducted over the past two decades, ranging from 'soft' mapping and management, reduction tools and methodologies to 'hard' material and recycling technologies. However, the current state of research is largely dominated by endeavours to manage waste that has already been produced. Hence, there is a need for a shift from 'end-of pipe' solutions that focus on on-site waste management to a source-based approach that is aimed at 'life cycle' analysis. This research engaged a sample population from the major UK architectural and contracting firms through 24 interviews to investigate the underlying origins, causes and sources of waste across all project life cycle stages. Respondents reported that designing out waste has never been the most glamorous end of sustainable design. Moreover, the results reveal that waste generation is affected by a wide practice of not embedding waste reduction in briefing and contractual documents, no baseline setting, and lack of designers' understanding of design waste origins, causes and sources. This is hindered by limited know-how and incoherent coordination and communication between project members and impeded by time constraints and disjointed design information. Collectively, these impediments disallow the consideration, engagement and implementation of designing out waste.

\section{Introduction}

The construction industry makes a vital contribution to the competitiveness and prosperity of the UK economy, has an annual turnover in excess of $£ 100$ billion, contributes $9 \%$ of GDP and provides employment for over three million people. It is, however, by far the greatest consumer of resources and producer of waste among all UK industries, being responsible for $32 \%$ of total waste generation, which equates to three times the combined waste produced by all households (Defra, 2007). Additionally, an estimated 25 million tonnes of construction and demolition waste ends up in landfill without any form of reuse or recovery, costing the industry around $£ 1$ billion per year in disposal costs (WRAP, 2008a). Consequently, construction waste management and minimisation has become a priority in UK environmental policy programmes such as the strategy for sustainable construction (SSC) (BERR, 2008), which contains a target to halve waste to landfill by 2012. A zero waste target was debated, but concerns regarding industry fragmentation and poor engagement led to its omission. The SSC recognised the importance of considering construction waste minimisation during design; hence the notion of 'designing out waste' as espoused in recent guidance for building projects (WRAP, 2008b, 2010).

Despite international academic endeavours over the past decade, design waste reduction research is limited and piecemeal and as such "more work is essential to investigate C\&D (construction and demolition) waste issues in project design' ( $\mathrm{Lu}$ and Yuan, 2010). The aim of this paper is to investigate the underlying origins, causes and sources across the Royal Institute of British Architects (RIBA) plan of work stages (RIBA, 2009) (Table 1). Within the context of this research

(a) 'origins' are denoted to project stages (e.g. RIBA plan of work stage A: Appraisal) or processes (e.g. architectural detailing) during which waste occurs

(b) 'causes' refer to direct and/or indirect waste generators (e.g. design changes, unclear specification)

(c) 'sources' are associated with waste generation provenance and contributory responsibility (e.g. client, architect).

Similarly, building 'design waste' is defined as waste arising from building sites as a direct and indirect result of the design process, including opportunities to reduce waste by all project stakeholders throughout the RIBA plan of work stages. The paper presents the research findings on the key causes of waste, their associated occurrence origins and sources across a project life cycle.

\section{State of research and knowledge gaps}

\subsection{Construction waste}

Although the ideal of construction waste reduction is well acknowledged and generally accepted, it is proving difficult to 
Waste and Resource Management

Volume 166 Issue WR3
Design waste mapping:

a project life cycle approach

Osmani
Plan of work stage

A Appraisal

B Design brief

C Concept

D Design development

E Technical design

F Production information

G Tender documentation

H Tender action

J Mobilisation

K Construction to practical completion

L After practical completion
Description

- Identification of client's requirements and possible constraints on development

- Studies to enable the client to decide whether or not to proceed and select a procurement route

- Preparation of strategic brief by or on behalf the client confirming key requirements and constraints

v Identification of procedures, organisational structure and consultants

- Development of the strategic brief into a full project brief

- Preparation of outline proposals and cost estimate

- Review of procurement route

- Complete development of project brief

- Preparation of detailed proposals

- Application for full development control approval

- Preparation of final proposals sufficient for coordination of all project components and elements

- Preparation of production information in sufficient detail to enable tenders to be obtained

- Application for statutory approvals

- Preparation and collation of tender documentation in sufficient detail to enable tenders to be obtained

- Identification and evaluation of potential contractors and/or specialists

- Obtaining and appraising tenders

- Submission of recommendations to the client

- Letting the building contract

- Appointing the contractor

- Issuing production information to the appointed contractor

- Arranging site handover to the contractor

- Administration of the building contract up to and including practical completion

Administration of the building contract after practical completion

- Making final inspections for settling the final account

Table 1. The RIBA plan of work stages (RIBA, 2009)

implement. Traditionally, wastes have been viewed by construction stakeholders as inevitable by-products. As such, managing on-site waste was often addressed within a legislative and health and safety context. However, the introduction of environmental regulations supported by rising client awareness is redefining the concept of waste from 'by-products' of construction processes to missed opportunities to cut costs, improve project performance and enhance companies' business prospects and corporate social responsibility.

For the past two decades, ever-increasing amounts of construction waste-related research have been conducted. Osmani (2011) pointed out that the ongoing research in the field of construction waste can be broadly categorised into 13 clusters, ranging from waste quantification and source evaluation to the development of on-site waste auditing tools and recycling. The bulk of construction waste research is largely guided by the waste hierarchy principles. Notwithstanding existing endeavours to facilitate on-site waste management improvement and set future baselines to help divert waste from landfill, the state of research is strongly dominated by 'end-ofpipe' issues. Indeed, tools, models and techniques have been developed to handle and better manage on-site construction waste segregation (Poon et al., 2001), waste data analysis (Treloar et al., 2003), waste auditing (McGrath, 2001) and reuse (Emmanuel, 2004). At the end of the waste management 
research spectrum, various waste recycling 'soft' decisionmaking and marketing methodologies (Knoeria et al., 2011; Spoerri et al., 2009) and 'hard' technologies (Osmani, 2013) have been developed as a last attempt to divert construction waste from landfill. Consequently, the literature in the field is piecemeal and by and large deals with waste that has already been produced - there is insufficient effort and no structured approach to address waste at source and specifically 'design waste'. It is widely argued that future waste efforts should focus on designing out waste (Osmani, 2011; Osmani et al., 2008; Poon, 2007). This is supported by Yuan and Shen (2010) who presented insights into construction waste research trends based on 87 published papers from eight journals. The study showed that there was no clear research direction by reporting that the bulk stream of publications was devoted to broad-brush topics such as environmental regulations and cost-benefit analysis. Similarly, Lu and Yuan (2010) developed a framework for understanding global construction waste research based on 131 journal papers. They indicated that current research in the field was related to construction and demolition stages, with very few attempts to investigate design waste.

The past few years have witnessed increasing yet still limited research on designing out waste (Osmani, 2011). For example, WRAP (2008b) introduced a guide to help architects reduce the amount of construction waste in their projects. The guide comprises five principles

(a) design for reuse and recovery

(b) design for off-site construction

(c) design for material optimisation

(d) design for waste-efficient procurement

(e) design for deconstruction and flexibility.

Although the content of WRAP (2008b) is a step forward to engage architects in designing out waste, the guide did not associate the proposed principles with all parameters of the design process environment, including stakeholders' coordination, communication and roles. More importantly, the guide failed to conduct a waste diagnosis across all design stages to map out the direct and indirect design waste origins, causes and sources that are critical in informing and implementing designing out waste principles and strategies.

Emerging information technologies, bar coding systems, GPS, GIS and wide area networks (WANs) are being introduced into construction waste research (Cheng et al., 2011). The recent emergence of building information modelling (BIM) techniques can be adopted to assist architects minimise waste in their design projects (Liu et al., 2011). Similarly, a steering committee consortium, chaired by the author, is in the process of developing a new British standard (BS 8895: Designing for material efficiency in building projects) that aims to provide principles and an implementation framework for waste prevention and minimisation during the design briefing stage of building projects. BS 8895 Part 1, scheduled for publication in July 2013, forms the foundation standard for a suite of future codes of practice intended to address specific and interrelated issues and processes of designing out waste in building projects across all design stages.

\subsection{Construction waste origins and causes}

There are a variety of different approaches to the classification of the main origins and causes of construction waste. For example, Ekanayake and Ofori (2000) grouped construction waste origins into design, operational, material handling and procurement origins. Additionally, they rated lack of information on drawings, complexity of detailing, selection of low-quality materials and lack of familiarity of alternative products as the most significant causes of waste. Bossink and Brouwers (1996) attributed design waste causes to errors in contract clauses or incomplete contract documents. Treloar et al. (2003) classified origins of construction waste into preconstruction and construction phases. They reported that during the pre-construction phase, waste occurs during planning and designing (e.g. lack of coordination with standardisation of materials and extra materials ordering, estimating), purchasing (e.g. overallowance and materials' variable dimensions) and dealings with manufacturers and suppliers (e.g. goods damaged during delivery and loading). Baldwin et al. (2006) identified a number of design waste causes, including building complexity (through the emergence of a variety of design specialities and responsibilities within the same project) and coordination and communications problems due to the multi-disciplinary nature of design projects in which the information that passes to contractors is highly variable and open to misinterpretation; inevitably contributing to waste generation. Equally, Osmani et al. (2008) reported that 'waste accepted as inevitable' and 'lack of training' are major challenges facing architects to design out waste. They concluded that this is made more complex when further waste is created directly or indirectly by other project stakeholders such as clients, contractors, subcontractors and suppliers.

There is general consensus in the literature that design variations leading to rework while construction works are in progress are significant waste causes (Cheng et al., 2011; Osmani, et al., 2006, 2008; Poon, 2007; Yuan and Shen, 2010). The main drivers for design variations during construction are related to ineffective communication between project stakeholders, complex designs, incomplete design information, unforeseen ground conditions and long project duration (Osmani, 2011). However, research studies that specifically identify design causes and sources in relation to their origins across all project stages are absent from the literature. Therefore, this research set out to investigate the 
underlying design waste causes, sources and origins using a holistic and structured approach.

\section{Research methodology}

The research adopted a qualitative research method to investigate the underlying design waste causes and sources, and their origins, throughout all project life cycle stages using a holistic and structured approach. The key design waste-related findings from the literature informed the design and content of 24 semistructured interviews, involving 12 architectural practices and 12 contracting firms. Partners and associates were targeted within the top $100 \mathrm{UK}$ architectural firms, as they oversee a significant number of projects and lead the decision-making process over the wider context of strategic, design and communication matters within their practices. A similar targeting approach was adopted for the top 100 UK contracting firms sustainability and environmental managers were selected owing to their interdisciplinary involvement with upstream corporate management and downstream project and site management.

The key construction waste causes emanating from a wide body of literature informed the structure and design of a semistructured interview schedule that was sent to the targeted architects and contractors prior to the interview proceedings. The interview schedule comprised 14 questions covering four sections: background information; construction waste minimisation at organisational level; design waste origins, causes and sources; and further thoughts. Each interview was conducted on a one-to-one basis and lasted approximately 60-90 min. The interviewer fuelled the debate on direct and indirect design waste sources through probes, which originated from the findings of the literature review.

The sequence of project stages of the RIBA plan of work protocol (Table 1) was used as a basis to identify design waste causes and sources. For effective capture of qualitative responses within the restricted timescale of interviews, interdependent stages in the protocol were streamlined into five project stages in the interview schedule

(a) briefing (appraisal and design brief )

(b) design (concept and design development)

(c) specification and detailing (technical design and production information)

(d) tender (production of documentation and action)

(e) construction (mobilisation and construction to practical completion)

\section{Results}

The findings of the interviews regarding design waste origins, causes and sources throughout the RIBA plan of work stages are reported and discussed below.

\subsection{Design waste causes and sources during briefing stages}

Table 2 summarises interviewees' insights into the most significant design waste causes and sources during the briefing stages (RIBA plan of work stages A (Appraisal) and B (Design brief)).

\subsubsection{Not a brief requirement}

There was consensus among all 24 interviewees that waste minimisation is generally not a brief requirement in projects. Responding contractors pointed out that the quality of instructions that architects get from clients is not always clearly stated and structured. Similarly, architects pointed out that the timescale of preliminary investigation prior to design is not sufficient for waste minimisation considerations. Clients' unawareness of the benefits, especially associated savings with waste reduction measures, was raised by all interviewees. It was emphasised by both architects and contractors that it is the responsibility of the quantity surveyor to identify potential benefits and communicate this to the client', who in turn should be taking the lead in issuing recommendations to inform stakeholders about the importance and impact of waste minimisation throughout the project life cycle. When probed on reasons for the lack of architects' and consultants' engagement in advising the client regarding waste control and management, all responding contractors were of the opinion that this is mainly due to time constraints imposed by clients. Equally, all architects reported that they work in accordance with a tight time schedule from start to end.

Poorly identified waste minimisation responsibility, which was identified by all participating architects and contractors, is leading to confusion on who should take the lead in driving the waste minimisation agenda and define how this will be implemented and monitored. All interviewees concurred that contracts should be clear on organisational responsibility and include contractual agreements with measurement benchmarks. However, all contractors reiterated the fact that this has to be client-led. Correspondingly, architects agreed that contract documents should set out waste minimisation goals and what is expected from each stakeholder.

There was a clear consensus among all interviewees that waste minimisation should be driven from the project outset and written into contract documents; as such, responsibilities would inevitably be established through all project stages.

\subsubsection{Insufficient incentives and enablers}

Although all interviewees acknowledged that designers have no legal responsibility to design out waste, contractors believed that architects have a pivotal role to play to inform their clients of any waste management actions to achieve certain levels in environmental assessment accreditation schemes such as BREEAM. On the other hand, the overwhelming majority 
of architects argued that proactive actions in this matter will need architects to go 'above and beyond their legal requirements', while financial incentives could objectively drive forward the waste agenda during the design process. This was further explained by one responding architect who pointed out that 'the client should perhaps set aside an additional fee for the architect to consider waste minimisation in the design process'. Conversely, a third of contractors disagreed by stating that design waste considerations should be part of architects' standard activities without additional financial incentives. This was echoed by a responding architect who compared the waste issue to health and safety considerations by recognising that, 15 years ago, architects did not think about health and safety too much because it was assumed to be the contractor's responsibility, yet it is now routinely considered part of the CDM Regulations (HM Government, 2007). He went on to argue that architects will eventually get to that stage with waste minimisation, but acknowledged that at the moment 'the idea has not permeated the architectural offices'.

All contractors were of the view that the briefing stage should comprise detailed research into how waste can be minimised through design. This was seen as an opportunity for architects and quantity surveyors to conduct a waste minimisation feasibility study in which information is assembled, a waste reduction target is set and a mechanism is put in place to monitor the process throughout the project life cycle. This should include working out rough ideas on materials, assessing their resource efficiency suitability and developing an initial cost plan. On the other hand, architects argued that waste minimisation is not a design priority and 'feasibility studies at the briefing stage will be looking at fundamental design parameters', as one architect put it. Another architect went further by stating that 'the extent at which waste minimisation will be considered at these stages will depend on how it fits into the most critical design issues'. However, all architects concurred that if waste reduction is not addressed at 'Appraisal' and certainly in the 'Design brief', then there is a potential to 'create a framework which will go on being wasteful all the way through the project life cycle'.

Participating architects admitted that, at present, waste minimisation endeavours are not considered during feasibility studies and the lack of waste-related information, especially benchmarking data, makes it even more difficult to pragmatically assess the potential for waste reduction during the design process. All contractors agreed that current waste minimisation baselines are piecemeal and not universally applied, and

\begin{tabular}{ll}
\hline Waste cause & Interviewees' responses \\
& $\begin{array}{l}\text { Architects } \text { Contractors } \\
\text { (out of 12) }\end{array}$ \\
& (out of 12)
\end{tabular}

Not a brief requirement

Not client-driven

No specific waste minimisation (WM)-related

briefing requirements

Client unaware of WM benefits $\quad 12$

Time constraints

Poorly defined WM responsibilities

WM not embedded in contract documents

Insufficient incentives and enablers

WM not a legislative requirement for designers 12

No designing out waste financial incentives 11

No WM feasibility studies $\quad 12$

Lack of recognised WM benchmarking and $\quad 12$

baselines

No WM target setting

Limited early interaction and coordination

among project team

WM not embedded in appraisal studies

$$
9
$$

\section{2}

12

12
12

12

12

12

11

2

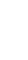

12

2

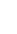

12
Client

Client

Architect, consultants

Client

Client

Client

Government

Client

Government, professional bodies (e.g. RIBA), architect, consultants,

Client, architect, consultants

Client, architect, consultants,

Architect, consultants

Table 2. Design waste causes and sources during briefing stages (RIBA plan of work stages A (Appraisal) and B (Design brief)) 
maintained that the client and the design team should be in a position to identify a waste minimisation target during the briefing stage. Most responding architects agreed that a baseline must be set, but stressed that enabling knowledge-based implementation mechanisms should be put in place to make such waste reduction targets feasible. On the other hand, few architects rejected the argument by stating that, at that point, they do not even know what the building is going to be made of, since 'Appraisal' and 'Design brief' are broad-brush stages.

\subsubsection{Lack of early collaborative engagement}

Little interaction among client, architect and consultant was a factor identified by all interviewees as an indirect cause of design waste. The need for a whole strategic team approach and decision-making was considered critical if waste minimisation was to filter through the entire process, which should be driven by a collaborative engagement of the client and the design team to embed it in appraisal studies and set up the foundation for a subsequent designing out implementation strategy.

\subsection{Design waste causes and sources during design stages}

Table 3 summarises the interviewees' insights into the salient design waste causes and sources during design stages (RIBA plan of work stages C (Concept) and D (Design development)). These are discussed below.

\subsubsection{Insufficient design timescale}

Due to time constraints, responding architects argued that they cannot adequately explore individual solutions and often make use of design and specification data from past projects. This was reinforced by one participating architect who emphasised that 'if there is no time to research systems, architects will keep defaulting and probably pull off what they have used or heard of before'. All architects suggested that if there was insufficient time, design issues are considered in order of importance. Contractors also commented that clients want 'buildings designed, built and occupied as quickly as possible'. They added, however, that if longer periods were allowed for pulling project details together, then issues such as waste and alternative methods of construction

Waste cause $\begin{array}{ll} & \frac{\text { Interviewees' responses Waste source }}{\text { Architects Contractors }} \\ & \text { (out of 12) (out of 12) }\end{array}$

Insufficient design timescale

Restricted design stage timescale leading to off-the-shelf design 12 solutions

Limited research and best practice review

12

Lack of architects' engagement

WM is not a design priority

No WM plan

Design complexity

Not designing to standard material sizes

No evaluation of impact of design solutions on waste generation

Limited involvement of architects in design development

Limited knowledge and guidance

Lack of understanding of design waste causes 12

Insufficient WM know-how

Limited design WM literature and best practice sharing

Lack of partnering commitment and coordination

Inadequate client-architect coordination

Poor coordination and communication between designers

Lack of contractors' early involvement

Design not frozen at the end of RIBA plan of work stage D

(Design development)

Table 3. Design waste causes and sources during design stages (RIBA plan of work stages C (Concept) and D (Design development))
Client

Architect, consultants

Architect, consultants Client, architect, consultants Architect, consultants Architect, consultants Architect, consultants Architect, consultants, specialist contractors

Architect, consultants

Architect, consultants Professional bodies (e.g. RIBA)

Client, architect

Architect, consultants

Client

Client, architect, consultants 
could be realistically considered. That said, they acknowledged that if designers have very tight deadlines to meet 'they will go with what they know'.

\subsubsection{Lack of architects' engagement}

All architects affirmed that a number of issues have to be taken into consideration during the design process; these include spatial as well as statutory requirements, and waste is not usually part of this agenda. They alluded that during 'Concept' and 'Design development' stages, architects start to crystallise physical shapes and dimensions, materials and specification. They opined that even though design waste will be an initial consideration, other issues soon distract architects from implementing it, such as 'getting through planning and other regulatory approvals', which require more urgent and thoughtful attention. However, most architects acknowledged that this process 'generates a certain amount of waste, even if it is not currently recognised and well defined as such'. There was a common agreement among contractors that design waste is the consequence of not initiating a waste management plan during design development, design complexity, not designing to standard material sizes and lack of impact assessment of design solutions on waste generation. Additionally, architects attributed their lack of engagement in designing out waste to their limited involvement in design development. This is due to an increasing amount of specialist design, particularly in design and build (D\&B) procurement. Architects' restricted contribution to the whole process, particularly their confined on-site supervisory roles, was also raised by all architects as a factor that could lead to indirect design waste. They concluded that up-coming architects will have little or no practical knowledge of site activities and will be unable to relate the impact of their design on onsite activities, including waste generation. The prevalent practice that architects are not responsible for the entire design was raised by all contractors who confirmed that 'architects rarely produce a design for $100 \%$ of the building' as most specialised design work packages in D\&B procurement (e.g. curtain walling) are done by specialist contractors; this leads to lack of design coordination and, ultimately, to design waste.

\subsubsection{Limited knowledge and guidance}

Lack of knowledge related to design waste origins, causes and sources on the one hand and waste reduction know-how during the design stage on the other were raised by both architects and contractors as indirect design waste causes. There was a consensus that this knowledge would assist architects to make informed decisions regarding waste minimisation. This was affirmed by one contractor who suggested that 'there is a need to conduct waste reduction assessments; know industry best practice, targets, and expected improvement outcome'. Similarly, most responding architects confirmed that waste-related guidance is essential at the start of a project and argued that measuring, acquiring and communicating such information is a key challenge that needs to be addressed. They also commented that insufficient waste reduction knowledge during design is closely related to the lack of guidance and information from organisations such as RIBA. When probed on the extent to which WRAP's document on designing out waste (WRAP, $2008 \mathrm{~b}$ ) is implemented in their projects, most architects reported that the document is helpful in terms of awareness but not as an implementation methodology, as it is too basic and some of its recommendations are not perfectly obvious to apply in a typical building project. Another architect added that 'a process chart that aids the architect in terms of defining potential areas of design waste causes and sources would be helpful and insightful'. Then again, a few responding architects and contractors acknowledged that it is the designer's responsibility to acquire knowledge that could contribute towards achieving and disseminating best practice.

\subsubsection{Lack of partnering commitment and coordination}

All contractors and most architects agreed that design waste can indirectly occur because of a lack of coordination between the architect and the client, leading to incomplete or inadequate capture of brief requirements and subsequent client-led changes during the construction stage. Responding contractors went further by associating waste generation with poor coordination and communication among designers. Architects opined, however, that this 'depends on the kind of contractor and the type of procurement route'. On the other hand, contractors maintained that early team collaboration should be firmly set during the early design stages and argued that if waste is not considered or known about at the briefing stages, it will be extremely difficult to carry it further in the design stages'. All contractors and over half the architects considered that early contractor involvement in the design process can lead to an informed designing out waste strategy and yield efficiencies in both time and resources. Finally, there was agreement among all interviewees that not freezing the design at the end of 'Design development' (stage D), as is the case for most projects, will inevitably lead to late changes during site operations and hence waste production.

\subsection{Design waste causes and sources during specification and detailing stages}

Table 4 summarises the respondents' views on the prevailing causes and sources of design waste during specification and detailing stages (RIBA plan of work stages E (Technical design) and $\mathrm{F}$ (Production information)). These are reported and discussed below.

\subsubsection{Inadequate coordination and communication}

Contractors agreed that wastage can indirectly occur because of lack of an effective design team collaboration and communication, which is primarily due to time constraints and uncoordinated and 'parallel' design packages. They indicated 
that design waste is the consequence of designers' coordination flaws that lead to on-site cutting and alterations to accommodate services due to incoherent detailing and production information coordination. Furthermore, contractors concurred that poor material size coordination and lack of joined-up detailing are major sources of design waste. This was exemplified in a practical example whereby not gauging the steelwork with block work resulted in a significant amount of block cutting. Most contractors identified weak linkages between designers and manufacturers as a significant indirect waste cause. This was illustrated by one contractor who suggested architects should utilise manufacturers 'and suppliers' visits to architectural offices 'to closely work with them to identify optimum ways to minimise waste through suitable material sizes'. On the other hand, architects argued that there are conflicts and ambiguities between standard sizes of different product manufacturers; for example, brick dimensions may work well on the outside but would not match plasterboard standard sizes on the inside, resulting in offcuts. As such, responding architects called for a whole-industry modular coordination approach.

\subsubsection{Incoherent material specification}

The general comment from contractors is that design waste is inevitable if no impact assessment of material specification on on-site waste generation is conducted and unsuitable materials are specified. The responsibility for specification-related waste production was ascribed by responding contractors to architects who allow 'aesthetics sometimes to overrun the practicalities', and manufacturers and suppliers for their poor quality of information

\begin{tabular}{|c|c|c|c|}
\hline \multirow[t]{2}{*}{ Waste cause } & \multicolumn{2}{|c|}{ Interviewees' responses } & \multirow[t]{2}{*}{ Waste source } \\
\hline & $\begin{array}{l}\text { Architects } \\
\text { (out of } 12 \text { ) }\end{array}$ & $\begin{array}{l}\text { Contractors } \\
\text { (out of } 12 \text { ) }\end{array}$ & \\
\hline \multicolumn{4}{|l|}{ Inadequate coordination and communication } \\
\hline Lack of full design team coordination & 10 & 12 & $\begin{array}{l}\text { Architect, consultants, client, } \\
\text { material manufacturers }\end{array}$ \\
\hline Incoherent 'joined-up' detailing between designers & 8 & 11 & $\begin{array}{l}\text { Architect, consultants, client, } \\
\text { material manufacturers }\end{array}$ \\
\hline Lack of material size coordination between designers & 5 & 12 & $\begin{array}{l}\text { Architect, consultants, material } \\
\text { manufacturers }\end{array}$ \\
\hline $\begin{array}{l}\text { Weak linkages between architects and material } \\
\text { manufacturers }\end{array}$ & 7 & 10 & Architect, material manufacturers \\
\hline Lack of industry modular coordination & 12 & 10 & Material manufacturers \\
\hline \multicolumn{4}{|l|}{ Incoherent specification } \\
\hline $\begin{array}{l}\text { No impact assessment of material specification on on-site } \\
\text { waste generation }\end{array}$ & 9 & 11 & Architect, consultants \\
\hline Unclear/incomplete/incorrect/unsuitable specification & 2 & 12 & Architect, consultants \\
\hline Over-specification & 12 & 12 & Architect \\
\hline Time constraints leading to off-the-shelf specification & 12 & 12 & Architect, consultants \\
\hline \multicolumn{4}{|l|}{ Detailing inconsistencies } \\
\hline Complex detailing & 12 & 12 & Architect, consultants \\
\hline Detailing errors & & 12 & Architect, consultants \\
\hline No impact assessment of detailing on material wastage & 10 & 12 & Architect, consultants \\
\hline Designers' restricted detailing responsibility & 12 & 7 & Client \\
\hline Time constraints leading to off-the-shelf details & 12 & 10 & Architect, consultants \\
\hline \multicolumn{4}{|l|}{ Limited use of modern methods of construction } \\
\hline Limited use of off-site construction techniques & 10 & 11 & Architect, consultants \\
\hline Architects' reluctance to design in prefabricated packages & 9 & 10 & Architect \\
\hline
\end{tabular}


provided to designers and to lack of flexibility in material sizes. Contractors also identified other design waste causes such as over-specification and unclear or incorrect specification. Most responding contractors considered these as major waste causes, particularly during 'Mobilisation' (stage J). They argued that if contractors get the right and full set of specifications, they can accordingly cost and accurately source materials. They concluded that amendments to incorrect or incomplete specifications require changes, which in turn lead to waste generation. Conversely, the majority of architects claimed that design information documents that specify materials and products that turn out to be unsuitable are not very common. However, all architects concurred that, owing to time pressure, they frequently revert to off the shelf material specification, which seems rather contradictory.

\subsubsection{Detailing inconsistencies}

All architects and contractors agreed that complex detailing is another cause of design waste, with one contractor explaining 'endless cutting processes are often required to get materials to the right detail specified by the architect'. This is in line with architects who acknowledged that 'if a building component is intrinsically difficult to build, then the site worker will not get it right the first time'. Although most contractors and architects concurred that there are usually checks to ensure that errors are minimised, they agreed that detailing errors occur as a result of time constraints (yet again) and poor communication among project stakeholders. To address detailing errors, participating contractors recommended that architects should not detail or specify in isolation without assessing the impact on the whole project performance, including waste generation. One contractor referred to a wholesome approach to design when he said 'it is not just dimensions of the unit but it should be the dimensions of the whole; in other words it is an understanding on how tolerances go together'. A similar view was expressed by an architect who stated 'it is not so much how the components fit together in the end but more how the components are getting together during the process'. Hence, architects need to be aware of the right sequence and contractors are able to contribute this knowledge.

Architects reported that designers' detailing responsibility is restricted in D\&B projects since specialist contractors produce most of the detail drawings of their respective work packages. This not fully coordinated specialist contractor-architect design information eventually generates design waste. Furthermore, all architects acknowledged that, in some cases, off the shelf detailing is practised due to timescale restrictions.

\subsubsection{Limited use of modern methods of construction}

The majority of contractors and architects suggested that design waste could be minimised by implementing off-site manufacturing and prefabrication methods during construction. One contractor recognised that standardised design seems to 'happen a lot more on the continent than it does in the UK, and it might be worth promoting this practice'. Architects agreed but cautioned that 'with prefabrication there will be a lot more coordination', especially at 'Mobilisation' (stage J) and 'Construction' (stage K). This was echoed by one contractor who argued that 'prefabrication requires higher accuracy with the final product as well as the setting out'.

\subsection{Design waste causes and sources during tender stages}

Respondents identified a number of key design waste causes and sources during tender stages (RIBA plan of work stages $G$ (Tender documentation) and $\mathrm{H}$ (Tender action)). The findings are summarised in Table 5.

\subsubsection{Waste minimisation not embedded in tender documents}

All respondents suggested that lack of waste minimisation enforcement, allocation of responsibilities and issuing guidance for its implementation in tender documents are significant waste causes during the tender stages. Equally, there was common agreement among architects and contractors that failure to include a full account of financial costings of waste in the bill of quantities is a major waste cause. As such, all participating contractors opined that if waste minimisation is not an integral part of tender documentation, it will not be considered a high priority. Similarly, all architects implied that if the waste issue was picked up at the tender stage, contractors would have enough time during the 'Tender production' stage to assess suitable options and forward recommendations to sub-contractors for potential areas and work packages where waste could be minimised. However, a number of architects were concerned that contractors might cost in extra expenses for waste management as part of their offer.

\subsubsection{Incomplete tender documents}

The majority of contractors considered late, incomplete or lack of design information clarity in tender documents causes of design waste. Contractors cited incomplete and poorly coordinated design and detailing information, an incoherent release schedule, and detail and specification under development in tender stages as determinants that frequently led to waste. Most architects related design information shortcomings to time constraints and argued that the client should allow the design team a reasonable timescale to produce full design information sets.

\subsubsection{Limited architectural input}

Two thirds of contractors and less than a quarter of architects opined that there is no waste minimisation design intent in tendering stages. Additionally, 11 out of the 12 contractors explained that architects could stress particular recommendations related to waste minimisation in their design, which 
would guide contractors and subcontractors to better manage on-site waste. Conversely, architects pointed out that this should fall within the client's remit since it is common practice that the architect's role is to brief and advise the client and claimed that 'if the client does not want this service, the architect cannot take it further'. This is a reiteration of earlier architects' comments for financial rewards from the client as an incentive to design out waste.

\subsection{Design waste causes and sources during construction stages}

The main design waste causes and sources during construction stages (RIBA plan of work stages $\mathrm{J}$ (Mobilisation) and $\mathrm{K}$ (Construction to practical completion)) as pinpointed by interviewees are summarised in Table 6.

\subsubsection{Limited 'Mobilisation' timescale and material over-ordering}

Most responding architects and all contractors emphasised that the lead-in period for planning and mobilisation, which is required to avoid high incidences of waste, is usually extremely limited in construction projects. All contractors argued that it is not often possible to further explore how to deliver the design while minimising factors that could lead to waste. Over two thirds of architects agreed that indirect waste production during 'Mobilisation' is closely associated with planning and coordination processes, and a tight mobilisation programme leads ultimately to on-site waste generation.

All contractors indicated that the quality and timely provision of design information received has a significant impact on effective material ordering and hence consequential waste generation. They concluded that if information is not released on time, the construction programme is affected and building work becomes out of sequence. This in turn affects material supply and storage, which eventually leads to waste. Responding architects generally agreed that this is a problematic issue and admitted that if architects spend longer designing and detailing, less time would be invested in detailing related changes and associated rework during site operations.

\begin{tabular}{|c|c|c|c|}
\hline \multirow[t]{2}{*}{ Waste cause } & \multicolumn{2}{|c|}{ Interviewees' responses } & \multirow[t]{2}{*}{ Waste source } \\
\hline & $\begin{array}{l}\text { Architects } \\
\text { (out of } 12 \text { ) }\end{array}$ & $\begin{array}{l}\text { Contractors } \\
\text { (out of } 12 \text { ) }\end{array}$ & \\
\hline \multicolumn{4}{|l|}{ WM not embedded in tender documentation } \\
\hline $\begin{array}{l}\text { Not issued and enforced in document control procedures } \\
\text { for tender and contract }\end{array}$ & 12 & 12 & Client \\
\hline Poorly defined WM responsibilities & 12 & 12 & Client \\
\hline Lack of WM tender's agreements & 12 & 12 & Client \\
\hline No target setting and implementation guidance & 12 & 12 & Client, architect, consultants \\
\hline No financial costing of waste in bill of quantities & 11 & 12 & Quantity surveyor \\
\hline \multicolumn{4}{|l|}{ Incomplete tender documentation } \\
\hline $\begin{array}{l}\text { Detailing and specification under development during } \\
\text { tender stage }\end{array}$ & 12 & 12 & Client, architect, consultants \\
\hline Not fully coordinated design and detailing information & 7 & 12 & $\begin{array}{l}\text { Architect, consultants, specialist } \\
\text { contractors }\end{array}$ \\
\hline Incomplete information from design team & 5 & 10 & $\begin{array}{l}\text { Architect, consultants, specialist } \\
\text { contractors }\end{array}$ \\
\hline Incoherent information release schedule & 8 & 11 & $\begin{array}{l}\text { Client, architect, consultants, } \\
\text { specialist contractors }\end{array}$ \\
\hline \multicolumn{4}{|l|}{ Limited architect's input } \\
\hline Lack of WM design intent & 2 & 9 & $\begin{array}{l}\text { Architect, consultants, specialist } \\
\text { contractors }\end{array}$ \\
\hline $\begin{array}{l}\text { Lack of architect's WM recommendations in tender } \\
\text { documentation and action }\end{array}$ & 4 & 11 & Architect \\
\hline
\end{tabular}




\subsubsection{Design changes and rework}

Client-led changes during site operations were identified by all interviewees as having far-reaching implications on waste generation. Responding architects indicated that, in most projects, clients make changes even after design has been signed off. This practice was considered by all interviewees to be prevalent in most building projects. All contractors reported that architect-led design changes result in major rework during site operations. However, architects argued that if they make design changes 'it is usually the consequence of last minute on-site client-led modifications' and they 'sometimes redraw and change detail drawings due to contractor's concerns over buildability'. Contractors, on the other hand, associated architects' design changes to their failure to correctly capture client's requirements during the briefing and design stages, considering the vagueness of the client's initial project brief.

All contractors and the majority of architects commented that subcontractors' activities (e.g. material over-ordering and wrong fitting) generate a considerable amount of on-site waste. They admitted, however, that subcontractors' overordering practice is usually the consequence of incomplete or unclear design information.

\subsubsection{Incoherent design information}

All contractors stated that inconsistencies between specification and drawings, and slow drawing revision and distribution lead to on-site waste generation and increased costs associated with rework. Most contractors reported that design and detailing flaws are major waste causes. However, nearly two thirds of architects suggested that it is more an issue of poor interpretation of drawings by contractors. They went further by claiming that design errors once construction starts are rare, yet they acknowledged that some details do not always work on-site, resulting in abortion of work. Few architects, on the other hand, admitted that lack of clear information at times, which can be ambiguous, could have a great impact on on-site waste production.

\section{Discussion}

Existing literature does not offer a holistic approach that considers the impact of multi-faceted project dynamics from the inception phase to the construction stage on design waste origins, causes and sources. These issues, summarised in Figure 1, were explored in this study. Six overarching thematic design waste causes emerged from the research findings, as are now discussed.

\begin{tabular}{|c|c|c|c|}
\hline \multirow[t]{2}{*}{ Waste cause } & \multicolumn{2}{|c|}{ Interviewees' responses } & \multirow[t]{2}{*}{ Waste source } \\
\hline & $\begin{array}{l}\text { Architects } \\
\text { (out of 12) }\end{array}$ & $\begin{array}{l}\text { Contractors } \\
\text { (out of } 12 \text { ) }\end{array}$ & \\
\hline \multicolumn{4}{|l|}{ Limited 'mobilisation' timescale and material over-ordering } \\
\hline Insufficient mobilisation time & 10 & 12 & Client \\
\hline $\begin{array}{l}\text { Missing/incomplete design information leading to } \\
\text { material ordering assumptions and over-ordering }\end{array}$ & 9 & 12 & Architect, consultants, specialist contractors \\
\hline $\begin{array}{l}\text { No thorough check of design information prior to } \\
\text { construction }\end{array}$ & 11 & 6 & Contractor \\
\hline \multicolumn{4}{|l|}{ Design changes and rework } \\
\hline Client-led & 12 & 12 & Client, architect, consultants \\
\hline Architect-led & 2 & 12 & Architect \\
\hline Contractor-led & 12 & 5 & contractor \\
\hline Subcontractor-led & 10 & 12 & Subcontractors \\
\hline \multicolumn{4}{|l|}{ Incoherent design information } \\
\hline Incomplete design information & 10 & 12 & Architect, consultants \\
\hline Inconsistencies between specification and drawings & 9 & 12 & Architect, consultants \\
\hline Slow drawing revision and distribution & 4 & 12 & Architect, consultants \\
\hline Design errors & 2 & 9 & Architect, consultants \\
\hline Detailing flaws & 8 & 12 & Architect, consultants \\
\hline
\end{tabular}




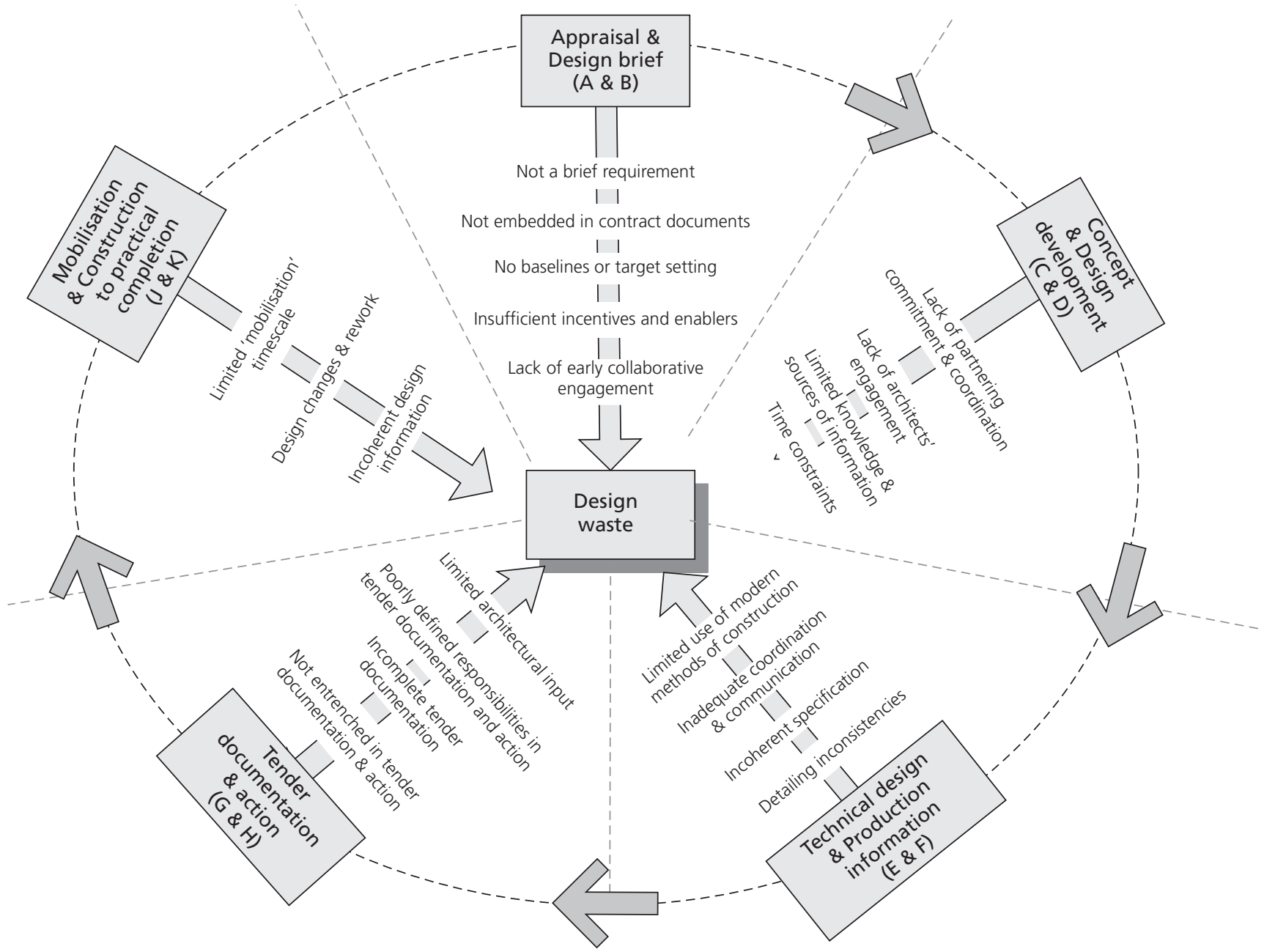

Figure 1. A project life cycle design waste mapping

\subsection{Imperceptible waste minimisation at project inception}

The research findings reveal that there is a strong correlation between clients being misinformed of waste minimisation benefits (namely cost-saving measures) and consequential design waste causes during the briefing stage and subsequent design and tender processes. Indeed, waste minimisation strategic recommendations are not routinely issued in briefing documents, written into contracts, and enforced in tender documents. This in turn leads to confusion over stakeholders' waste minimisation roles and responsibilities throughout all project stages.

\subsection{Insufficient drivers for designing out waste}

Since designers are not legally required to design out waste in their projects, responding architects maintained that waste minimisation is often a moral expectation upon the architect, which is often not sufficient pressure to consider it in design. They added that financial rewards would have more effect on designing out initiatives. On the other hand, responding contractors believed that failure (by architects and quantity surveyors respectively) to conduct waste minimisation feasibility appraisals and cost-benefit studies during the briefing stages is a significant waste cause.

\subsection{Lack of architects' understanding of design waste causes and sources}

The findings of the interviews suggest that architects do not initiate waste minimisation measures in their projects because they assume that waste occurs during the construction stage and is rarely generated during the design process. This perception has partially resulted in limited architects' waste reduction input during the design process and recommendations in tender stages. 


\subsection{Limited waste-related benchmarking data and guidance}

Architects and contractors agreed that existing construction waste benchmarking data are piecemeal and not universally applied, making it difficult to confidently set waste reduction baselines and targets in construction projects. Although responding architects recognised that a few existing designing out waste guides (e.g. WRAP, 2008b) are helpful, they emphasised that there is a lack of robust methods to assist them making informed designing out waste decisions in a holistic manner that considers all design dynamics in construction projects.

\subsection{Inadequate project stakeholders' coordination and communication}

Poor coordination and communication among project stakeholders were identified as common design waste causes across all project stages. These encompass: inadequate client-architect communication; lack of joined-up design coordination between the architect and consultants; material sizing and detailing information; uncoordinated architect-specialist contractor design information; and ineffective coordination between the architect and material manufacturers.

\subsection{Time constraints}

Time constraints were deemed by all architects and contractors as an overarching design waste cause across all project stages. Tight project schedules prevent architects and consultants conducting feasibility and cost-benefit studies. Similarly, insufficient design time schedules act as a setback to researching designing out waste strategies and assessing the impact of design options on waste generation. Equally, limited timescales during specification, detailing and tender stages result usually in incomplete and uncoordinated design information, forcing architects in some cases to revert to off-the-shelf design, specification and detailing solutions used in previous projects. Additionally, not freezing the design at the 'Design development' stage, which was indicated by all respondents as a significant trigger for design changes during the construction stage, was highlighted as a direct consequence of time constraints.

\section{Conclusions}

This research engaged a sample population from the major UK architectural and contracting firms to investigate the underlying origins, causes and sources of waste across all project life cycle stages. The results suggest that design waste

(a) is affected by the wide practice of not having waste minimisation as a brief requirement, the absence of baseline settings and lack of designers' understanding of design waste origins

(b) is hindered by limited 'know-how' and incoherent coordination and communication between project members (c) is impeded by time constraints and disjointed design information.

Cumulatively, these issues disallow due waste minimisation consideration, implementation and monitoring during the design stages. Furthermore, the RIBA plan of work (Table 1) suggests that design should be frozen at the end of 'Design development' (stage D), but this is rarely the case in practice; hence design changes are made during the construction stage, which are also attributed to ineffective client-designer communication and incoherent coordination among project stakeholders. The fact that design is not generally completed before site operations start is a current practice reality. Furthermore, and owing to contemporary procurement trends such as D\&B projects, architects are less involved in the design of the entire building and production information; this in turn restricts their responsibilities in detailing, specification and on-site supervision duties.

This research extends previous work on design waste through a structured stakeholder-oriented approach to analyse design waste determinants. It is hoped the findings will help architects comprehend and assess the impact of their designs on on-site waste generation and assist project stakeholders in the formulation of informed building waste minimisation frameworks and strategies. Similarly, the design waste mapping results may stimulate further research associated with waste reduction at source.

\section{Acknowledgements}

The author wishes to sincerely thank all the architectural and contracting companies and individuals who contributed to the research findings. Their insightful participation and thorough engagement in the interviews are greatly appreciated.

\section{REFERENCES}

Baldwin A, Poon C, Shen L, Austin A and Wong I (2006)

Designing out waste in high-rise residential buildings: analysis of precasting and prefabrication methods and traditional construction. Proceedings of International Conference on Asia-European Sustainable Urban Development, Chongqing, China, pp. 1-9.

BERR (Business, Enterprise and Regulatory Reform) (2008) Strategy for Sustainable Construction. BERR, London, UK. Bossink BAG and Brouwers HJH (1996) Construction waste: quantification and source evaluation. Journal of Construction Engineering and Management 122(1): 55-60.

Cheng X, Chen J and Chen M (2011) Construction waste management: current status and directions for further study. Applied Mechanics and Materials 71-78: 4628-4633.

Defra (Department for Environment, Food and Rural Affairs) (2007) Waste Strategy for England 2007. The Stationery Office, London, UK. 
Ekanayake LL and Ofori G (2000) Construction material source evaluation. Proceedings of 2nd Southern African Conference on Sustainable Development in the Built Environment, Pretoria, South Africa, pp. 1-6.

Emmanuel R (2004) Estimating the environmental suitability of wall materials: preliminary results from Sri Lanka. Building and Environment 39(10): 1253-1261.

HM Government (2007) Health and Safety: the Construction (Design and Management) Regulations. The Stationery Office, London, UK.

Knoeria C, Binder CR and Althaus H (2011) Decisions on recycling: construction stakeholders' decisions regarding recycled mineral construction materials. Resources, Conservation and Recycling 55(11): 1039-1050.

Liu Z, Osmani M, Demian P and Baldwin A (2011) The potential use of BIM to aid construction waste minimisation. Proceedings of the Joint CIB W78-W102 International Conference on Computer Integrated Construction, Sophia Antipolis, France, pp. 1-13.

Lu W and Yuan H (2010) Exploring critical success factors for waste management in construction projects of China. Resources, Conservation and Recycling 55(2): 201-208.

McGrath C (2001) Waste minimisation in practice. Resources, Conservation and Recycling 32(3-4): 227-238.

Osmani M (2011) Construction waste. In Waste: A Handbook for Management (Letcher TM and Vallero DA (eds)). Elsevier, Oxford, UK, pp. 207-218.

Osmani M (2013) Innovation in cleaner production through waste recycling in composites. Management of Environmental Quality 24(1): 1-9.

Osmani M, Glass J and Price AD (2006) Architect and contractor attitudes towards waste minimisation. Waste and Resource Management 59(2): 65-72.
Osmani M, Glass J and Price AD (2008) Architects' perspectives on construction waste minimisation by design. Waste Management 28(7): 1147-1158.

Poon CS (2007) Reducing construction waste. Waste Management 27(1): 1715-1716.

Poon CS, Yu ATW and Ng LH (2001) On-site sorting of construction and demolition waste in Hong Kong. Resources, Conservation and Recycling 32(2): 157-172.

RIBA (Royal Institute of British Architects) (2009) Plan of Work: Multi-disciplinary Services. RIBA, London, UK.

Spoerri A, Langa DJ, Bindera CR and Scholza RW (2009) Expert-based scenarios for strategic waste and resource management planning - C\&D waste recycling in the Canton of Zurich, Switzerland. Resources, Conservation and Recycling 53(10): 592-600.

Treloar GJ, Gupta H, Love PED and Nguyen B (2003) An analysis of factors influencing waste minimisation and use of recycled materials for the construction of residential buildings. Management of Environmental Quality 14(1): 134-145.

WRAP (Waste and Resources Action Programme) (2008a) Halving Waste to Landfill: Are You Committed? WRAP, Banbury, UK.

WRAP (2008b) Designing out Waste: A Design Team Guide for Buildings. WRAP, Banbury, UK.

WRAP (2010) Designing out Waste: A Design Team Guide for Civil Engineering. WRAP, Banbury, UK.

Yuan $\mathrm{H}$ and Shen $\mathrm{L}$ (2010) Trend of the research on construction and demolition waste management. Waste Management 31(4): 670-679.

\section{WHAT DO YOU THINK?}

To discuss this paper, please email up to 500 words to the editor at journals@ice.org.uk. Your contribution will be forwarded to the author(s) for a reply and, if considered appropriate by the editorial panel, will be published as a discussion in a future issue of the journal.

Proceedings journals rely entirely on contributions sent in by civil engineering professionals, academics and students. Papers should be 2000-5000 words long (briefing papers should be 1000-2000 words long), with adequate illustrations and references. You can submit your paper online via www.icevirtuallibrary.com/content/journals, where you will also find detailed author guidelines. 